\title{
Anti-insulin-like growth factor-IIP3 DNAzymes inhibit cell proliferation and induce caspase- dependent apoptosis in human hepatocarcinoma cell lines
}

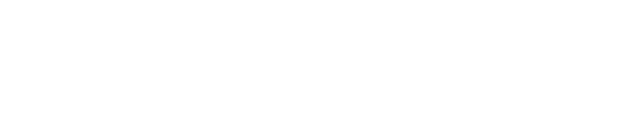

\author{
Min Zhang' \\ Gregor PC Drummen² \\ Su Luo' \\ 'Medical Department, Beihua \\ University, Jilin, People's Republic of \\ China; ${ }^{2}$ Cellular Stress and Ageing \\ Program, Bionanoscience and Bio- \\ Imaging Program, Bio \& Nano- \\ Solutions, Düsseldorf, Germany
}

Correspondence: Gregor PC Drummen Bio \& Nano-Solutions, Helmutstraße 3a, D-40472, Düsseldorf, Germany Tel +49 2I I 22973648 Fax +49322 22407500

Email gpcdrummen@bionano-solutions.de

Su Luo

Beihua University, Huashan Road 3999, Jilin I32100, People's Republic of China Tel +864326460 80I I

Email Is63390680@sina.com
Background: Insulin-like growth factor II (IGF-II) is a fetal growth protein and an important proangiogenic factor controlled by four promoters (P), of which P2-P4 are inactive in the adult liver. Reactivation and dysregulation of IGF-IIP3 in particular is associated with the attenuation of apoptosis and increased proliferation in a number of liver cancer cell types. Its involvement in experimental liver carcinogenesis makes it a potential target for cancer gene therapy. We designed two IGF-IIP3 specific DNAzymes (DRz1 and DRz2) that target IGF-IIP3 messenger RNA (mRNA) with the aim of reducing IGF-II expression through promoter 3.

Methods: IGF-IIP3 mRNA and protein expression levels were assessed using real-time polymerase chain reaction and gel electrophoresis/western blotting after transfection with Lipofectamine $^{\circledR}$ in SMMC-7721, Huh7, and HepG2 cell lines. Cell proliferation was determined via MTT assay; apoptosis was evaluated by fluorescence microscopy and with flow cytometry; procaspase-3 and -9 expression were detected via western blotting; and caspase activity was assayed colorimetrically. Standard procedures were used to calculate means and standard deviations, and $P$-values below 0.05 were considered to indicate significant differences.

Results: DRzs were transfected into hepatocellular carcinoma cells and the results showed that DRz1, in particular, could decrease the expression of IGF-IIP3 by nearly $50 \%$. Furthermore, DRz1 significantly inhibited cell proliferation and induced apoptosis. In addition, the downregulation of IGF-IIP3 expression was associated with increased caspase-3 and -9 activity in SMMC-7721 cells after 24 hours of transfection. In all experiments, the efficacy of DRz2 to influence IGF-IIP3 levels and associated effects remained second to DRz1.

Conclusion: Overall, these results suggest that DRz1-based targeting of IGF-IIP3 mRNA might have antitumorigenic activity and may potentially provide the basis for a novel therapeutic intervention in liver cancer treatment, although further development is required.

Keywords: DNAzymes, proliferation, apoptosis, IGF-II, caspase, hepatocellular carcinoma, cancer

\section{Introduction}

Hepatocellular carcinoma (HCC) is a major cause of morbidity and mortality worldwide, being the fifth most common cancer in males and the seventh in females. ${ }^{1,2}$ HCC is characterized by its rapid development, early metastasis, and, because of the heterogeneity in the disease, a difficult to establish prognosis and survival time. ${ }^{1,3,4}$ Traditional surgical therapies, radiotherapy, chemotherapy, and a combination of traditional Chinese medicine and synthetic drugs do not significantly improve prognosis, ${ }^{3,5,6}$ mainly because of late presentation of large tumors, and only $10 \%-20 \%$ of the carcinomas can 
be removed in toto surgically. The only US Food and Drug Administration- and European Medicines Agency-approved systemic therapeutic agent for unresectable HCC, sorafenib $\left(\right.$ Nexavar $^{\circledR}$; Onyx Pharmaceuticals, Inc., San Francisco, CA, USA), is an oral multikinase inhibitor that targets, amongst others, Raf kinase and VEGF/PDGF (vascular endothelial growth factor/platelet-derived growth factor) receptor tyrosine kinase signaling, ${ }^{6}$ suffers from limited availability and clinical experience in those areas with the highest incidence of HCC, including Asia. ${ }^{5}$ Furthermore, even though clinical trials reported a statistically relevant increase in mean survival, this survival comes about through attenuation of disease progression, but ultimately does not represent a solution that leads to disease remission, which would be desirable. Therefore, novel approaches that lead to new and affordable treatments are urgently required worldwide.

Insulin and insulin-like growth factors (IGFs) are key regulators of both energy metabolism and growth, and regulate physiological processes at both the organismal and cellular level. Besides dysregulation of hepatocyte growth factor (HGF/MET), Wingless (Wnt/ $\beta$-catenin/FZD), transforming growth factor (TGF)- $\alpha$ /epidermal growth factor receptor (EGFR), and TGF- $\beta / T \beta R$ signaling, derangements of the IGF signaling pathway have also been implicated in various forms of cancer, including HCC and are major factors in their development and spread; this has been recently reviewed in detail by Pollak, ${ }^{7}$ and Breuhahn et al, ${ }^{8}$ and Breuhahn and Schirmacher. ${ }^{9}$

IGF-II is a fetal growth protein and an important proangiogenic factor. The human $I G F-I I$ gene is a complex imprinted gene - only one allele in a locus is active, depending on parental origin - assigned to $11 \mathrm{p} 15$, spanning 30 $\mathrm{kbp}$ and containing nine exons and four different promoters (P1-P4). ${ }^{10}$ The regulation of human IGF-II expression is tightly and intricately controlled, predominantly through epigenetic mechanisms (reviewed in Chao and D'Amore ${ }^{11}$ ), expression of receptors, and IGF-binding proteins that enable its synthesis under various physiological conditions and in a tissue- and development-specific manner. ${ }^{12}$ Current knowledge indicates that dysregulation of IGF-II is a major factor involved in the attenuation of apoptosis and proliferation in $\mathrm{HCC}$, thereby contributing to uncontrolled tumor growth and chemoresistance. In the adult liver, the promoter P1 is active, whilst P2-P4 activities are decreased or completely deactivated ( $\mathrm{P} 3$ and $\mathrm{P} 4$ are the main active promoters during fetal development). ${ }^{8,13}$ Increased levels of IGF-II in HCC cells result from transcriptional activation such as loss of promoterspecific imprinting or reactivation of the fetal promoters, ${ }^{9,13}$ and, in HCC and cell lines expressing IGF-II, activity of fetal P3 and P4 was determined to be upregulated, ${ }^{14}$ although there is some controversy about the extent of $\mathrm{P} 4$ upregulation.

Deoxyribozymes (DNAzymes or DRzs) are singlestranded catalytic DNAs that bind to complementary sequences in a target messenger RNA (mRNA) by WatsonCrick base pairing, forming DNA:RNA duplex structures that cleave adjacent and predetermined phosphodiester linkages (reviewed in McManus and $\mathrm{Li}^{15}$ and Schlosser and $\mathrm{Li}^{16}$ ). This cleavage occurs because the bound DNA facilitates attack of the 2 '-hydroxyl group on the adjacent phosphodiester bond, which causes transesterification and concomitant cleavage of the RNA backbone. Consequently, mRNA is prevented from undergoing successful translation, which results in a downregulation of IGF-II levels. Even though there are various structurally related DRzs, the 10-23 DRz in particular has been proposed as a general model for DRzs ${ }^{17,18}$ and forms the basis for engineering suitable DRzs for biological research. A 10-23 DRz has a catalytic domain of 15 deoxyribonucleotides flanked by two arms, each with a 7-9 deoxyribonucleotide substrate-recognition domain, and in vitro analysis has shown that this type of DRz effectively cleaves substrate mRNA at purine and pyrimidine junctions. ${ }^{19,20}$ Furthermore, 10-23 DRzs have been shown in both in vitro and in vivo experiments to inhibit the expression of their target and dependent genes. ${ }^{20,21}$ Moreover, DRzs are able to attenuate the progression of a variety of pathologies in animal models and show significant potential as therapeutic tools. ${ }^{19,22}$

This study is a continuation of our previous work in which we showed that two previously designed IGF-II DNAzymes could inhibit invasion, cell motility and migration of SMMC-7721 cells in vitro. ${ }^{23}$ Because of the aforementioned properties of HCC cells, we focused on targeting human IGF-IIP3 mRNA with suitable DRzs, since we hypothesized that IGF-II levels might be reduced to such an extent that the excessive tumor-cell-associated proliferation and antiapoptotic properties might be attenuated or abolished. To test this hypothesis, the antitumorigenic properties of the synthesized DRzs were evaluated in various HCC cell lines, isolated from different patients with various genetic defects that all resulted in the same tumorigenic genotype, ie, SMMC-7721, Huh7, and HepG2 cell lines.

\section{Materials and methods DNAzyme design}

Two DNAzymes, designated DRz1 and DRz2, were designed as previously described, ${ }^{23}$ via methodology outlined by Dass et al. ${ }^{24}$ Briefly, a region of $10-23 \mathrm{DRz}$ was made by 
incorporating $8 \mathrm{bps}$ arms complementary to the target gene at each side of the catalytic motif. ${ }^{25}$ As a control, a sequenceinverted inactive DNAzyme (DRz ${ }^{\text {inv }}$ ) was designed based on the flip sequence of DRz1. Both DNAzymes were synthesized by Shanghai Sangon Biotechnology Co, Ltd (Shanghai, People's Republic of China). The sequences of human IGFIIP3 mRNA templates and corresponding DNAzymes were designed as follows (arrows indicate the cleavage point):

Template 1: 5' AGACACCAA 1 UGGGAAUC 3'

DRzl : 5' GATTCCCAGGCTAGCTACAACGATG GTGTCT 3'

Template 2: 5' GGAAGUCGA UGCUGGUG 3'

DRz2 : 5' CACCAGCAGGCTAGCTACAACGAC GACTTC 3'

DRz1 ${ }^{\text {inv }}: 5^{\prime}$ TCTGTGGTAGCAACATCGATCGGAC CCTTAG 3'

\section{Cell lines and cell culture}

The various HCC cell lines used in this study, SMMC7721, HepG2, Huh7, and healthy human control (HL-7702) hepatocytes were purchased from the Cell Bank and Type Culture Collection of the Chinese Academy of Sciences (Shanghai Institute of Cell Biology, Chinese Academy of Sciences, Shanghai, People's Republic of China). Cells were maintained and cultured in Dulbecco's Modified Eagle's Medium (DMEM) supplemented with 10\% fetal bovine serum (Gibco; Life Technologies, Grand Island, NY, USA), $100 \mathrm{IU} / \mathrm{mL}$ penicillin, $100 \mathrm{IU} / \mathrm{mL}$ streptomycin, and $2 \mathrm{mmol} / \mathrm{L} \mathrm{L}$-glutamine in a humidified atmosphere $\left(5 \% \mathrm{CO}_{2}\right.$, $37^{\circ} \mathrm{C}$ ). Cells were counted in suspensions using a Cedex analyzer (Innovatis AG, Bielefeld, Germany).

\section{Transfection}

Transfection was performed according to the manufacturer's protocol with Lipofectamine ${ }^{\circledR} 2000$ (Invitrogen; Life Technologies) and $10 \mu \mathrm{L}$ expression vector in $250 \mu \mathrm{L}$ serumfree medium. The concentration of the DNAzymes used was $1.0 \mu \mathrm{g}$ in $250 \mu \mathrm{L}$ medium $(4 \mu \mathrm{g} / \mathrm{mL}=0.39 \mathrm{pmol} / \mu \mathrm{L})$. After 6 hours, the medium was replaced with fresh serumcontaining DMEM and the culture was allowed to grow for an additional 24 hours.

\section{Cell proliferation assay}

Cell proliferation and, concomitantly, DRz cytotoxicity were assessed via 3-(4,5-dimethylthiazol-2-yl)-2,5diphenyltetrazolium bromide (MTT) assay, ${ }^{26}$ which is based on the reduction of a yellow soluble tetrazole to an insoluble purple formazan in respiring cells. Cells were seeded at an initial density of $5 \times 10^{4}$ cells/well in a 96-well plate and transfected with $0.4 \mu \mathrm{g}$ DRzs in $100 \mu \mathrm{L}$ medium $(4 \mu \mathrm{g} / \mathrm{mL}=0.39 \mathrm{pmol} / \mu \mathrm{L})$ for 24,48 , and 72 hours. At the end of the treatment, media containing the DRzs were carefully aspirated and $200 \mu \mathrm{L}$ medium with $20 \mu \mathrm{L}$ of a $5 \mathrm{mg} / \mathrm{mL}$ MTT (Sigma-Aldrich, St Louis, MO, USA) solution in phosphate-buffered saline (PBS) was added to each well. After 4 hours' incubation at $37^{\circ} \mathrm{C}$, the medium was removed and $100 \mu \mathrm{L}$ dimethyl sulfoxide was added to each well. The optical absorbance (A) was measured at $490 \mathrm{~nm}$ using a BioTek ELX800 multi-well reader (BioTek, Winooski, VT, USA). The percentage viable cells (VC) was calculated according to:

$$
\begin{aligned}
\mathrm{VC}(\%)= & (\mathrm{A} \text { of experimental group } / \mathrm{A} \text { of control } \\
& \text { group }) \times 100
\end{aligned}
$$

\section{Real-time polymerase chain reaction ( $q P C R)$}

Human IGF-IIP3 and $\beta$-actin (housekeeping control) PCR primers were designed using Primer Express software (Applied Biosystems; Life Technologies) based on their published sequences: IGF-IIP3 (381 bp), 5'-ATGGGAATGCCAATGGGGAAG-3' (forward) and 5'-CTTGCCCACGGGGTATCTGGG-3' (reverse); and $\beta$-actin (318 bp), 5'-ATCATGTTTGAGACCTTCAACA-3' (forward) and 5'-CATCTCTTGCTCGAAGTCCA-3' (reverse). Total RNA of HCC cells was isolated with TRIzol reagent (Invitrogen), according to the manufacturer's instructions. To avoid DNA contamination, total RNA was treated with RNase-free DNase I (Takara, Kyoto, Japan) for 60 minutes at $37^{\circ} \mathrm{C}$ and extracted once with the TRIzol reagent. The RNA purity was determined from the $260 / 280 \mathrm{~nm}$ absorbance ratio and the RNA integrity was assessed by determining the intensity of the $28 \mathrm{~S}$ and $18 \mathrm{~S}$ rRNA bands after formaldehyde agarose gel electrophoresis. Total RNA $(2 \mu \mathrm{g})$ was subjected to reverse transcription using a RevertAid ${ }^{\mathrm{TM}}$ First-Strand cDNA Synthesis Kit (Thermo Fisher Scientific, Waltham, MA, USA) with a random hexamer primer. For real-time PCR, $2 \mu \mathrm{L}$ cDNA solution was used. Genes were amplified in a $25 \mu \mathrm{L}$ reaction volume using SYBR Green (Applied Biosystems; Life Technologies) on a MiniOpticon ${ }^{\mathrm{TM}}$ Real-Time PCR System (Bio-Rad Laboratories, Hercules, CA, USA). The temperature profile comprised an initial denaturation step at $95^{\circ} \mathrm{C}$ for 5 minutes, followed by 40 cycles at $95^{\circ} \mathrm{C}$ for 10 seconds, $58^{\circ} \mathrm{C}$ for 15 seconds, and $72^{\circ} \mathrm{C}$ for 10 seconds before melting curve analysis. The specificity of the amplified products was evaluated via agarose gel electrophoresis and 
was further verified with automated cycle sequencing. To ensure consistency in threshold cycle $(\mathrm{Ct})$ values, triplicate reactions were performed and mean $\mathrm{Ct}$ values were used for calculating the relative expression levels. The $\mathrm{Ct}$ values were analyzed as described previously by Zhou et $\mathrm{al}^{27}$ and the normalized $\mathrm{Ct}$ values for each gene were subjected to a Student's $t$-test with two-tailed distribution to determine statistical significance (95\% confidence interval). Final measurements were carried out in triplicate and the mean values were calculated. For standardization purposes, $\beta$-actin was used as an internal control in each sample.

\section{Western blotting}

After transfection, cells were washed twice with pre-cooled PBS and, subsequently, $10^{6}$ cells were treated with radio immunoprecipitation assay (RIPA) buffer (50 mM Tris [pH 8.0], $150 \mathrm{mM} \mathrm{NaCl}, 0.1 \%$ sodium dodecyl sulfate [SDS], 1\% NP40, and 0.5\% sodium deoxycholate) containing protease inhibitors (1\% cocktail and $1 \mathrm{mM}$ PMSF [phenylmethylsulfonyl fluoride]). Total protein extracts were separated on 15\% SDS-PAGE (sodium dodecyl sulfate polyacrylamide gel electrophoresis) and transferred to polyvinylidene difluoride (PVDF) membranes. The membrane was blocked with Tris-buffered saline containing $0.1 \%$ Tween 20 (pH 7.6 [TBST]) for 1 hour at room temperature. Subsequently, the PVDF membrane was immunoblotted overnight at $4^{\circ} \mathrm{C}$ with the first antibody (vide infra) solution $(1: 1,000)$. After washing twice with TBST, the membrane was incubated with horseradish peroxidase-labeled secondary goat anti-mouse $\mathrm{IgG}_{2 \mathrm{a}}$-B antibody (sc-2073; Santa Cruz Biotechnology, Inc., Santa Cruz, CA, USA) for 1 hour at room temperature and thereafter washed three times with TBST. The final detection was performed with enhanced chemiluminescence western blotting reagents (GE Healthcare Bio-Sciences Corp, Piscataway, NJ, USA) and the membranes were exposed to Lumi-Film Chemiluminescent Detection Film (Roche Applied Science, Basel, Switzerland).

Loading differences were normalized by using a monoclonal $\beta$-actin antibody against the housekeeping control $\beta$-actin. The primary antibodies used in this study included anti-IGFII (SC-7435), anti-caspase-3 (SC-7272), anti-caspase-9 (SC70507), and anti- $\beta$-actin (SC-130301) and were all acquired from Santa Cruz Biotechnology, Inc.

\section{Fluorescence microscopic evaluation of DRz uptake and apoptosis}

Cellular uptake of the DRzs was determined by labeling them on the $5^{\prime}$-side with fluorescein isothiocyanate (FITC) and incubating cells as described above and subsequent fluorescence microscopic evaluation.

Changes in cell morphology, especially in the nucleus, in response to the DRzs were evaluated by fluorescence microscopy using diamidino-phenylindole (DAPI) staining. Cells were seeded at $2 \times 10^{4}$ cells/well on glass slides in 24 -well plates and treated with $4 \mu \mathrm{g} / \mathrm{mL}$ DRz1 or DRz2 for 24 hours. Subsequently, treated cells were fixed with $70 \%$ precooled methanol $\left(-20^{\circ} \mathrm{C}\right)$ for 5 minutes, followed by staining with $100 \mu \mathrm{L} / \mathrm{mL}$ DAPI solution for 10 minutes at room temperature in the dark. The results were evaluated with an Olympus BX51TRF upright fluorescence microscope equipped with a photomicrograph system (Olympus Corporation, Tokyo, Japan). Image processing and analysis was performed with Image J (version 1.55; US National Institutes of Health, Bethesda, MD, USA).

\section{Flow cytometry with annexin V-FITC/ propidium iodide staining}

For quantitative assessment of apoptosis, cells were doublestained with annexin V-FITC and propidium iodide (PI) and analyzed by flow cytometry on a FACSAria ${ }^{\text {TM }}$ flow cytometer (BD Biosciences, San Jose, CA, USA). Briefly, cells $\left(1 \times 10^{5}\right)$ were harvested and stained with annexin V-FITC and PI double-staining kit (Kaiji Bio Co., Nanjing, People's Republic of China), according to the manufacturer's instructions. Cells were immediately analyzed by flow cytometry and the signals from apoptotic cells were localized in the lower right quadrant of the resulting dot plot.

\section{Caspase- 3 and caspase- 9 activation assays}

The caspase- 3 and caspase-9 colorimetric assay kits (Kaiji Bio Co.) were used to determine caspase- 3 and caspase-9 activation in SMMC-7721 cells, according to the manufacturer's instructions. Briefly, cells were lysed by incubating with cell-lysis buffer on ice for 1 hour. Subsequently, the resulting mixture was centrifuged at $10,000 \times \mathrm{g}$ for 1 minute. Enzymatic reactions were carried out in a 96-well microplate. To each reaction sample, $50 \mu \mathrm{L}$ cell lysate was incubated with substrate for 4 hours at $37^{\circ} \mathrm{C}$, before measurement of the absorbance at $405 \mathrm{~nm}$ with a BioTek ELX800 multi-well reader. Two additional controls, one without cell lysate and the other without substrate, were included. Total protein was determined by the Coomassie brilliant blue method.

\section{Statistics and data analysis}

Measurements were performed in triplicate and results are expressed as means \pm standard deviation. Data were obtained from at least three independent experiments. Analysis of 
variance (ANOVA) for multiple comparisons was carried out using statistical analysis software (SPSS Inc, Chicago, IL, USA). In all cases, values of $P$ below 0.05 were considered to indicate significant differences.

\section{Results}

\section{Inhibition of IGF-IIP3 mRNA and protein expression by DRzs}

We hypothesized that, by preventing transcription of IGFIIP3 mRNA via selective cleavage with suitable DRzs, IGF-II protein levels can be significantly reduced. In this fashion, the antiapoptotic and proliferative properties of IGF-II might be attenuated or even abolished in the best-case scenario and, as such, provide a potential alternative therapeutic option compared with more conventional methods. To this end, realtime PCR and western blotting analysis were used to detect the effects of DRzs on target gene expression in response to various concentrations (Figure 1) to determine the optimal incubation concentration and subsequently the effect of the treatment length (Figure 2).

The results in Figure 1A and B show that both DRz1 and DRz2 were able to inhibit IGF-IIP3 mRNA and, concomitantly, protein expression. These effects were concentration-dependent, since both mRNA levels and IGF-II protein expression
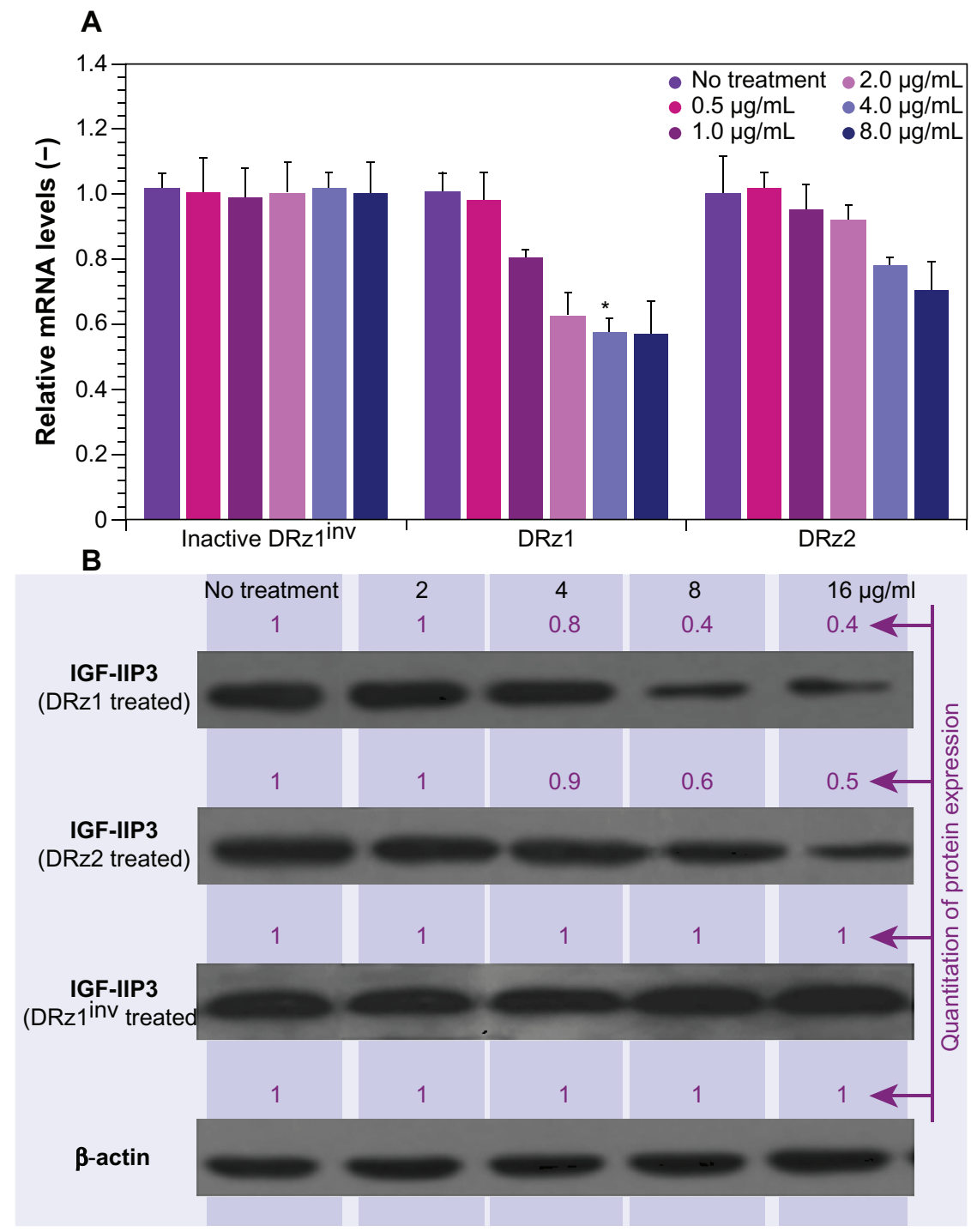

Figure I Effect of DRz concentration on the expression of IGF-IIP3 in SMMC-772I cells.

Notes: (A) mRNA expression of IGF-IIP3 was significantly inhibited by different concentrations of DRzs $(I \mu \mathrm{g} / \mathrm{mL}=0.098 \mathrm{pmol} / \mu \mathrm{L})$. The cells were transfected with the indicated concentrations of DRzI, DRz2, or DRzlinv for 24 hours. Data shown are means \pm SD of normalized relative IGF-IIP3 mRNA levels ( $n \geq 3$ ). *Significant difference to control $(P<0.05)$; (-) dimensionless units. (B) IGF-IIP3 protein expression was quantified via densitometry and compared with the "no treatment" control. The maximal gray value was set to $I$ and all other results are expressed relative to this value (black) $(n \geq 3)$.

Abbreviations: DRz, deoxyribozyme (DNAzyme); DRzlinv, inactive DRz; IGF-IIP3, insulin-like growth factor II promoter 3; mRNA, messenger RNA; SD, standard deviation. 

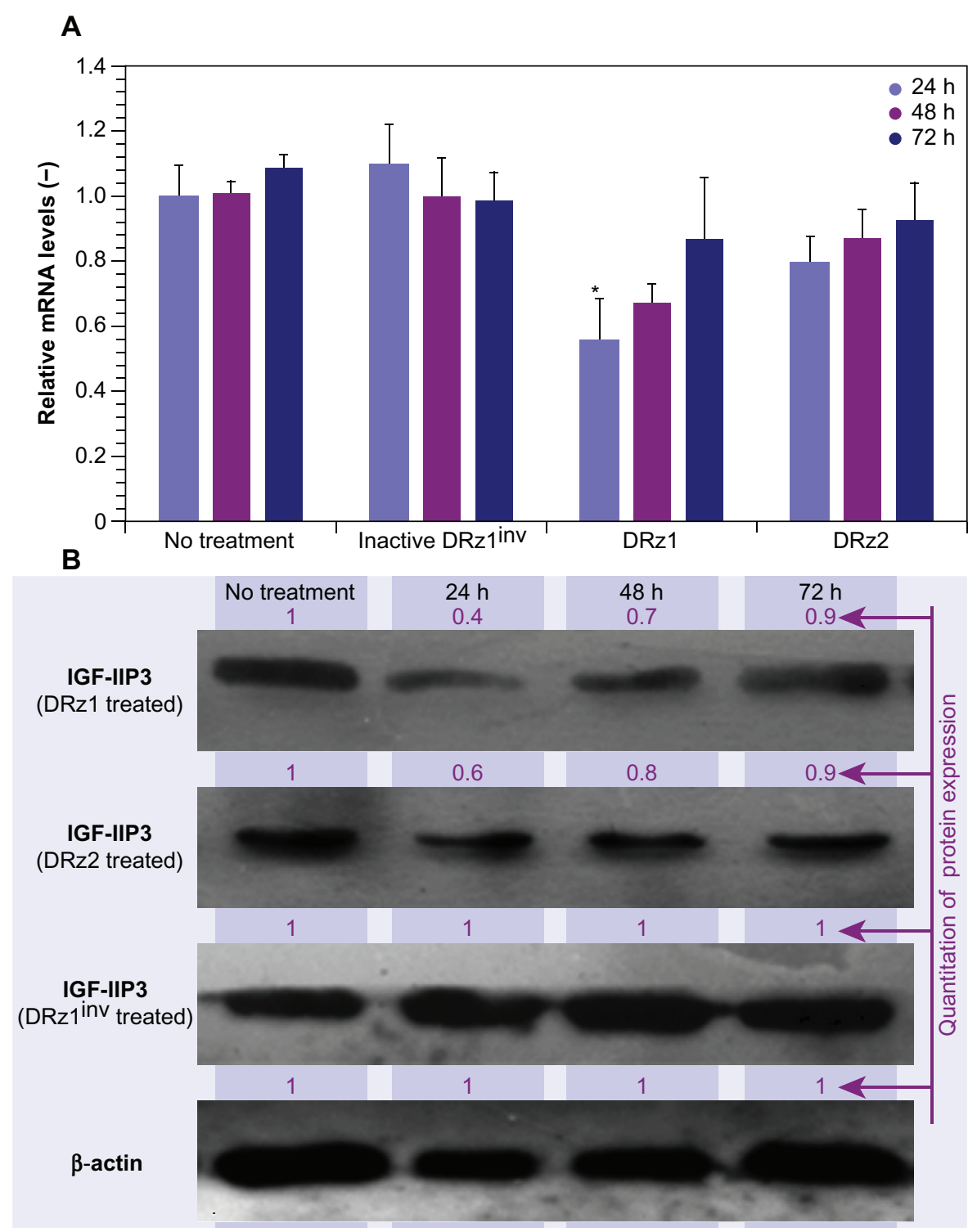

Figure 2 Effect of DRzs on the expression of IGF-IIP3 in SMMC-772I cells.

Notes: (A) mRNA expression of IGF-IIP3 was significantly inhibited by DRzs. The cells received either no treatment or were transfected with $4 \mu \mathrm{g} / \mathrm{mL}(0.39 \mathrm{pmol} / \mu \mathrm{L}) \mathrm{DRz}$, DRz2, or DRz I inv. Data shown are means \pm SD of relative IGF-IIP3 mRNA expressed compared to control (no treatment) ( $\geq 3)$. *Significant difference to control $(P<0.05)$. (B) Protein expression of IGF-IIP3 was equally inhibited by both DRzs. IGF-IIP3 protein expression was quantified via densitometry and compared with the "no treatment" control. The maximal gray value was set to I and all other results were expressed relative to this value (black). Note that the $24-h o u r$ transfection with DRzI exhibited the strongest reduction in IGF-IIP3 protein expression levels $(n \geq 3)$.

Abbreviations: DRz, deoxyribozyme (DNAzyme); DRzI inv, inactive DRz; IGF-IIP3, insulin-like growth factor II promoter 3; mRNA, messenger RNA; SD, standard deviation.

decreased with increasing concentration after 24 hours of treatment. Furthermore, no significant additional effect was seen at the highest concentration, and therefore $4 \mu \mathrm{g} / \mathrm{mL}$ DRzs was determined to be the optimal concentration. Evaluation of IGF-II expression in healthy HL-7702 human control hepatocytes showed no significant expression on real-time PCR or western blot, as expected, and no negative effects were observed upon incubation with the DRzs.

Figure $2 \mathrm{~A}$ and $\mathrm{B}$ show a time-dependent response to the incubation with $4 \mu \mathrm{g} / \mathrm{mL}$ after 24,48 , and 72 hours of treatment with IGF-IIP3-DRzs; however, these effects were transient, since both mRNA levels and IGF-II protein expression increased with time to reach near normal levels after 72 hours of treatment. Furthermore, the mRNA knockdown reached a maximum of $56 \%$, and thus remained incomplete. In addition, the results show that DRz1 more effectively reduced IGF-IIP3 mRNA levels and IGF-II protein expression than DRz2.

To exclude that this was due to inadequate cellular uptake or differences in intracellular localization, we labeled 
the DRzs with FITC at the $5^{\prime}$ end and incubated cells for 24 hours. Fluorescence microscopic evaluation showed that all DRzs, including the control, localized homogenously throughout the cytoplasm and the nucleus (Figure 3) in approximately $84 \%$ of the cells.

It is likely that, at least partially, degradation of the DRzs by cell-endogenous exonucleases abolishes the knockdown of IGF-IIP3 expression and leads to restoration of IGF-IIP3 expression over time. Nonetheless, it should be borne in mind that IGF-II overexpression in HCC is associated with upregulation of the fetal transcripts determined by both P3 and P4 promoters, ${ }^{14}$ and it is therefore entirely possible that knockdown via P3 alone cannot reduce IGF-II beyond approximately $50 \%$. Further investigations will be necessary to determine the contribution of the $\mathrm{P} 3$ and $\mathrm{P} 4$ promoters to the overall IGF-II expression and whether simultaneous knockdown of these is required.

To evaluate the capacity of the DRzs to inhibit IGFIIP3 protein expression in different human HCC cell lines from different human isolates, SMMC-7721, HepG2, and Huh7 cells were treated with the DRzs for 24 hours and IGF-IIP3 protein levels were evaluated on western blot. As shown in Figure 4, both DRz1 and DRz2 were generally able to inhibit IGF-IIP3 protein expression in all HCC cell lines tested. The levels could be reduced to approximately half of the control level. The most pronounced knockdown effect was induced by DRz1 in SMMC-7721 cells. Conversely, the inhibitory effect of the DRzs was weakest in Huh7 cells.

\section{Effects of DRzs on cell proliferation}

Since IGF-II is a potent growth factor that stimulates proliferation, and because the DRzs were able to significantly reduce its expression, the antiproliferative effect of the DRzs was determined via MTT assay in human SMMC7721 cells. Following 24, 48 and 72 hours' treatment with DRzs, the MTT assay showed that DRzs could inhibit the growth of SMMC-7721 cells (Figure 5A). Compared to control, DRz1 inhibited SMMC-7721 cell proliferation
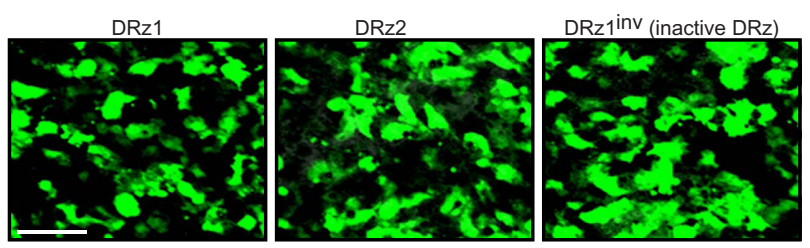

Figure 3 Fluorescence microscopic evaluation of DRz cellular uptake and intracellular distribution.

Note: Cells were transfected with $4 \mu \mathrm{g} / \mathrm{mL}$ ( $0.39 \mathrm{pmol} / \mu \mathrm{L}) \mathrm{DRz}$ I, DRz2, or DRz I inv (control) and cultured for 24 hours to a final cell density of $2 \times 10^{4}$. Bar: $200 \mu \mathrm{m}$. Abbreviations: DRz, deoxyribozyme (DNAzyme); DRzI inv, inactive DRz. by approximately $30.2 \% \pm 5.1 \%, 25.1 \% \pm 2.6 \%$, and $15.6 \% \pm 1.1 \%$ after 24,48 , and 72 hours' treatment, respectively. These results are in accordance with the mRNA and protein expression data. The attenuation of the proliferation presents itself in the same transient fashion as the mRNA and protein levels (Figure 2), and DRz1 equally shows the largest effect, reducing cell growth to a maximum of $30 \%$ after the first 24 hours.

Comparison of the growth inhibitory effect of the DRzs in various HCC cell lines showed that, despite some differences in effectiveness, previously established from the mRNA and protein levels, both DRzs were able to notably attenuate cell proliferation, with negligible differences between these (Figure 5B). In all cell lines, DRz1 clearly showed the larger inhibitory effect.

\section{Microscopic assessment of the morphological changes in $\mathrm{HCC}$ cell lines}

DRz-treated (24 hours) SMMC-7721, HepG2, Huh7, and control cells were stained with DAPI for fluorescence microscopic evaluation of nuclear morphology. As shown in Figure 6, normal nuclear morphology with less bright staining is noticeable in the untreated group and inactive

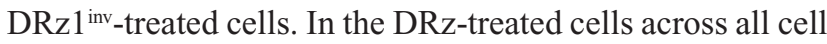
lines, several properties distinct of apoptotic and preapoptotic cells are specifically noticeable. In all cell lines, brightly fluorescent hyper-condensed chromatin (white arrows) and some apoptotic bodies and fragmented nuclei (red arrows) can be seen. Furthermore, nuclei in transition from a preapoptotic to an apoptotic state, with partial chromatin condensation, are noticeable. Some of the differences are highlighted in the pseudo-color figures (see Figure 6, top). Generally, both DRz1 and DRz2 were able to induce apoptosis, and cell death occurred, exhibiting the classic signs of apoptosis - nuclear fragmentation, chromatin condensation, and membrane blebbing (from phase-contrast assessment). However, only about one third of the cells were apoptotic; DRz1, on average, induced apoptosis in $27 \%$ of the cells versus $21 \%$ for DRz2, as evaluated from a limited number of fluorescence micrographs.

\section{Flow cytometric evaluation of DRz- induced apoptosis in HCC cell lines}

To further assess the capacity of the DRzs to induce apoptosis in HCC cells, SMMC-7721 cells were treated with the DRzs and the externalization of phosphatidylserine via annexin V-FITC staining was assessed by flow cytometry; PI was used to count nuclei. In this way, statistically relevant populations 


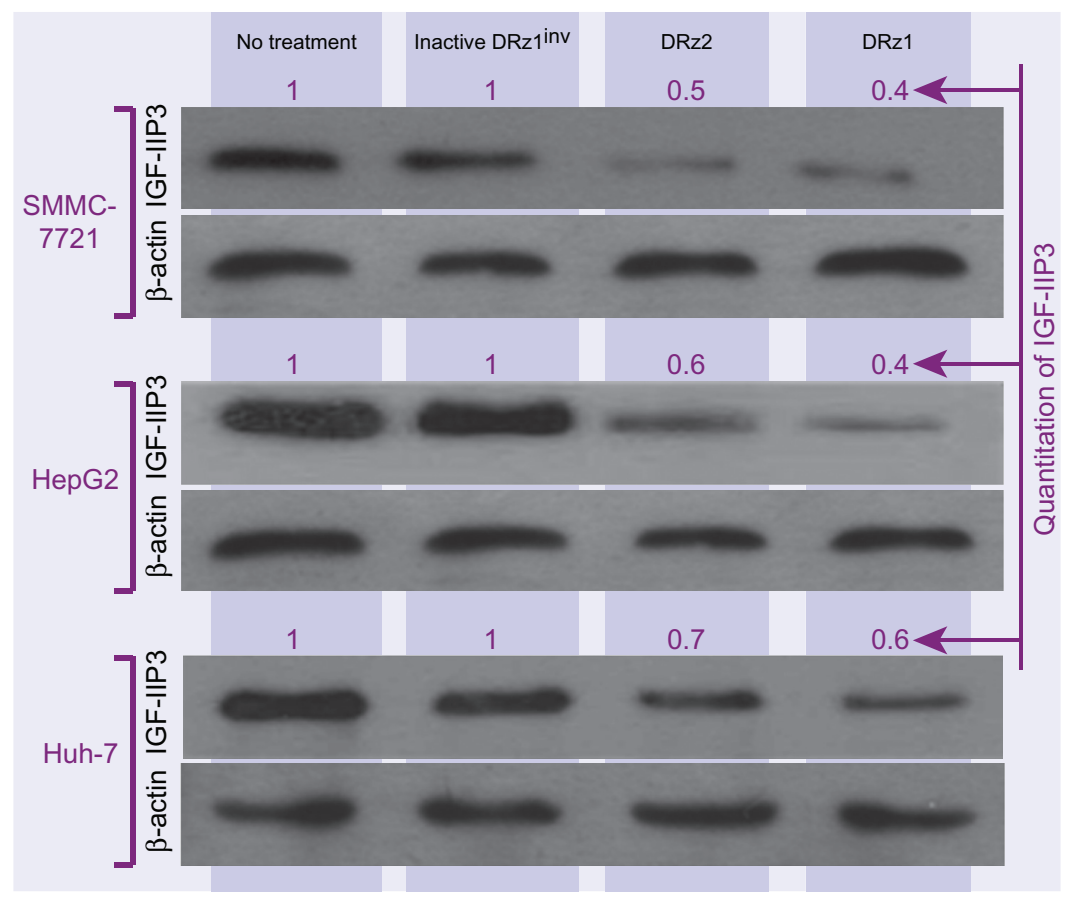

Figure 4 Effect of $4 \mu \mathrm{g} / \mathrm{mL}(0.39 \mathrm{pmol} / \mu \mathrm{L})$ DRzs on the expression of IGF-IIP3 in various HCC cell lines.

Notes: Protein expression of IGF-IIP3 was significantly inhibited by DRzs in SMMC-772I cells, HepG2 cells, and Huh7 cells. IGF-IIP3 protein expression was quantified by densitometry, with the maximal gray value set to $I(n \geq 3)$.

Abbreviations: DRz, deoxyribozyme (DNAzyme); HCC, hepatocellular carcinoma; IGF-IIP3, insulin-like growth factor II promoter 3.

and both early-stage (lower-right quadrant) and late-stage (upper-right quadrant) apoptotic and necrotic subpopulations could be evaluated (Figure 7).

The results in Figure 7A and B are representative for the performed experiments and show that both DRz1 and DRz2 maximally induced early-stage apoptosis after 24 hours in $\sim 25 \%$ and $20 \%$ of the cell population, respectively. Their effect deteriorated gradually over the following 48 hours, with equivalent trends for both DRzs, to approximately $5 \%$, which confirms the previous results and the transience of the IGF-IIP3 inhibition. Conversely, DRz1 more efficiently induced late-stage apoptosis and necrosis $(\sim 40 \%)$, and this effect remained stable for up to 48 hours (Figure 7B), after which it steeply dropped to $12 \%$.

To explore whether DRz treatment could equally induce apoptosis in other HCC cell lines, and thus to evaluate HCC treatment universality, DRz-mediated cell death was measured via flow cytometry in HepG2 and Huh 7 cells (Figure 8). HepG2 and Huh 7 cells were treated analogous to SMMC-7721 cells with both DRzs for 24 hours. The results in Figure 8 show that both DRzs could equally induce cell death in HepG2 and Huh 7 cells compared with SMMC7721 cells. Furthermore, DRz1 was again more potent than DRz2. These preliminary results in cellulo indicate uniformity in the capability of the synthesized DRzs to induce cell death in $\mathrm{HCC}$ cells, irrespective of their origin and genetic make-up.

\section{DRzI induces apoptosis through caspase activation}

Cellular apoptosis is predominantly mediated through the caspase family of cysteine aspartic acid-specific proteases that cleave their substrates after specific tetrapeptide motifs, specifically after aspartic acid, and are involved in signaling of cellular remodeling and demolition, which ultimately leads to controlled cell death. ${ }^{28-30}$ Generally, caspase activation occurs via three pathways: the extrinsic (death receptor signaling); the intrinsic, mitochondrion-dependent (cellular stress); and the granzyme B (from cytotoxic T lymphocytes or natural killer cells) pathways.

Caspases are present in normal cells as protease inactive precursor enzymes (zymogens), denoted procaspases, and can be divided into initiating caspases, which are able to auto-activate and initiate the proteolytic processing of other caspases and effector caspases (eg, caspase-3, caspase-6, and caspase-7), which are involved in the initial cleavage of proteins. During the initiation phase of apoptosis, the apoptosome, a large protein complex, forms in the presence of adenosine triphosphate or deoxyadenosine triphosphate and predominantly consists of cytochrome $\mathrm{c}$ and apoptotic 

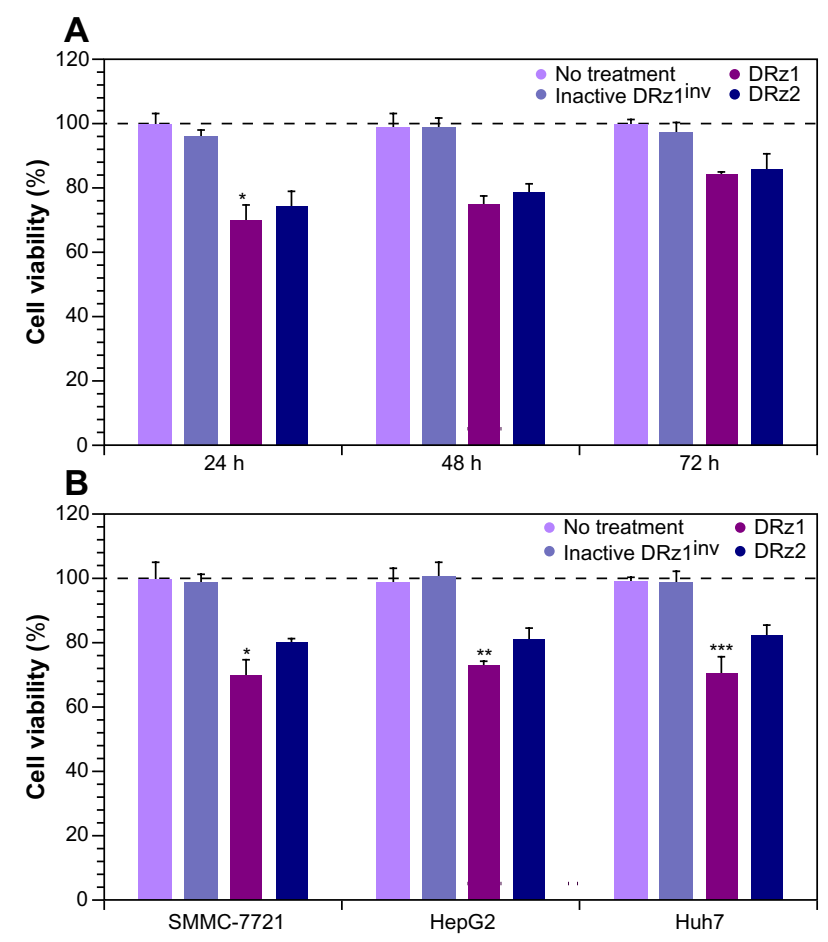

Figure 5 Assessment of cell proliferation via MTT assay.

Notes: (A) Cell proliferation and survival of SMMC-772I cells (initial density $5 \times 10^{4}$ cells $/$ well $)$ in the presence of $4 \mu \mathrm{g} / \mathrm{mL}(0.39 \mathrm{pmol} / \mu \mathrm{L})$ of the IGF-IIP3 DRzs for a maximum of 72 hours. (B) Comparison of cell proliferation and survival of SMMC-772I, HepG2, and Huh7 cells (initial density $5 \times 10^{4}$ cells/well) in response to $4 \mu \mathrm{g} / \mathrm{mL}(0.39 \mathrm{pmol} / \mu \mathrm{L})$ of the IGF-IIP3 DRzs after 24 hours. All data are means \pm SD from triplicates $(n \geq 3)$. *P $<0.05$; **P $<0.0$ I; ***P $<0.00$ I.

Abbreviations: DRz, deoxyribozyme (DNAzyme); IGF-IIP3, insulin-like growth factor II promoter 3; MTT, 3-(4,5-dimethylthiazol-2-yl)-2,5-diphenyltetrazolium bromide; SD, standard deviation.

protease-activating factor-1 (APAF1). Once formed, the apoptosome recruits procaspase-9, which results in the allosteric activation of caspase- 9 . Consequently, caspase- 9 activates, amongst others, caspase- 3 , which, in turn, activates caspases- 6 and -7 and is involved in various processes during the demolition phase of apoptosis.

Since caspase- 3 is activated as a result of cellular stress via the intrinsic apoptotic signal transduction pathway, we tested procaspase- 3 and -9 expression after DRz treatment for the optimal treatment time, which was determined from the previous experiments to be 24 hours (vide supra). In comparison to controls, procaspase- 3 and procaspase- 9 expression levels decreased significantly in DRz1-treated SMMC-7721 cells (Figure 9A). To confirm that DRz1 and DRz2 induce apoptosis via the caspase-dependent intrinsic pathway, we measured caspase- 3 and -9 activities in response to 24 hours of DRz treatment in SMMC-7721 cells. Compared to controls, the activities of caspase- 3 and -9 increased significantly and, in conformity with all previous experiments, DRz1 showed the strongest caspase induction (Figure 9B).
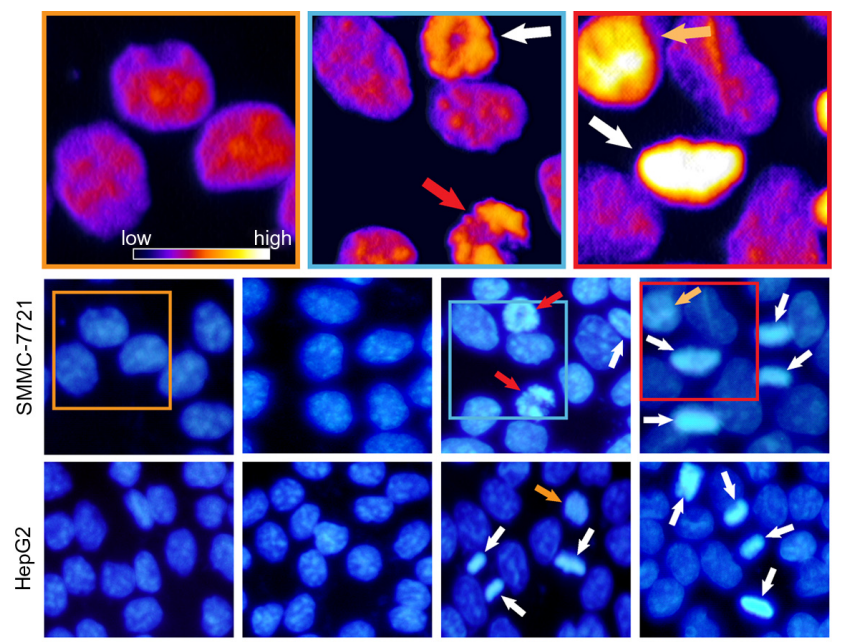

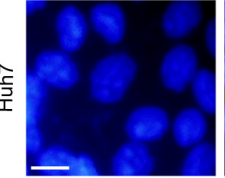

No treatment

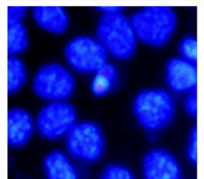

Inactive DRz $1^{\text {inv }}$

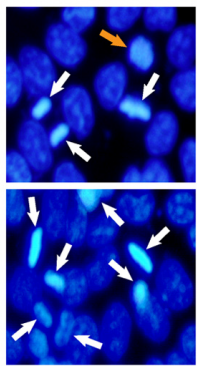

$\mathrm{DRz} 1$

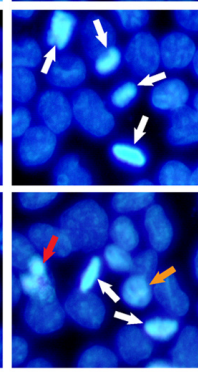

DRz2
Figure 6 Fluorescence microscopic evaluation of nuclear morphological changes (DAPI stained) in response to IGF-IIP3 DRzs.

Notes: Cells were transfected with $4 \mu \mathrm{g} / \mathrm{mL}(0.39 \mathrm{pmol} / \mu \mathrm{L}) \mathrm{DRz}$, DRz2, or DRzl ${ }^{\text {inv }}$ (control), cultured for 24 hours to a final cell density of $2 \times 10^{4}$, and subsequently stained with $100 \mu \mathrm{L} / \mathrm{mL}$ DAPI. Arrows indicate fragmented (red), hyper-condensed (white), and nuclei entering condensation/fragmentation (orange), which are further highlighted in the magnified pseudo-color insert. CLUT = relative intensity profile indicating the amount of nuclear condensation. Bar: $20 \mu \mathrm{m}$.

Abbreviations: DAPI, diamidino-phenylindole; DRz, deoxyribozyme (DNAzyme); DRzI Inv, inactive DRz; IGF-IIP3, insulin-like growth factor II promoter 3.

Similar trends were observed in the other HCC cell lines. These results suggest that DRz1 and DRz2 induce apoptosis in a caspase-dependent manner.

\section{Discussion}

DNAzymes are synthetic antisense DNA molecules with catalytic activity towards target mRNA. These enzyme mimics have been developed as inhibitory agents for a myriad of diseases and their potential has been recognized in the past decade. For instance, a DNAzyme against the zinc finger transcription factor Egr-1 inhibited restenosis in ballooninjured rat carotid arteries, ${ }^{31}$ whereas DZ1133 was developed to target the conserved genomic RNA sequence of the RSV nucleocapsid protein and inhibit respiratory syncytial viral infection; ${ }^{32}$ recently, the anti-MMP9 DNAzyme AM9D was shown to reduce breast tumor growth in a MMTV-PyMT mouse model of breast cancer. ${ }^{33}$ DNAzymes have also been developed for use in bioanalytical in vitro applications, such as the detection of specific DNA sequences via peroxidaselike colorimetric/chemiluminescent assays, determination of telomerase or methyltransferase activity, determination of metal cations $\left(\mathrm{Ag}^{+}, \mathrm{K}^{+}, \mathrm{Hg}^{2+}, \mathrm{Pb}^{2+}\right.$, or $\left.\mathrm{Cu}^{2+}\right)$, and amplified 
A
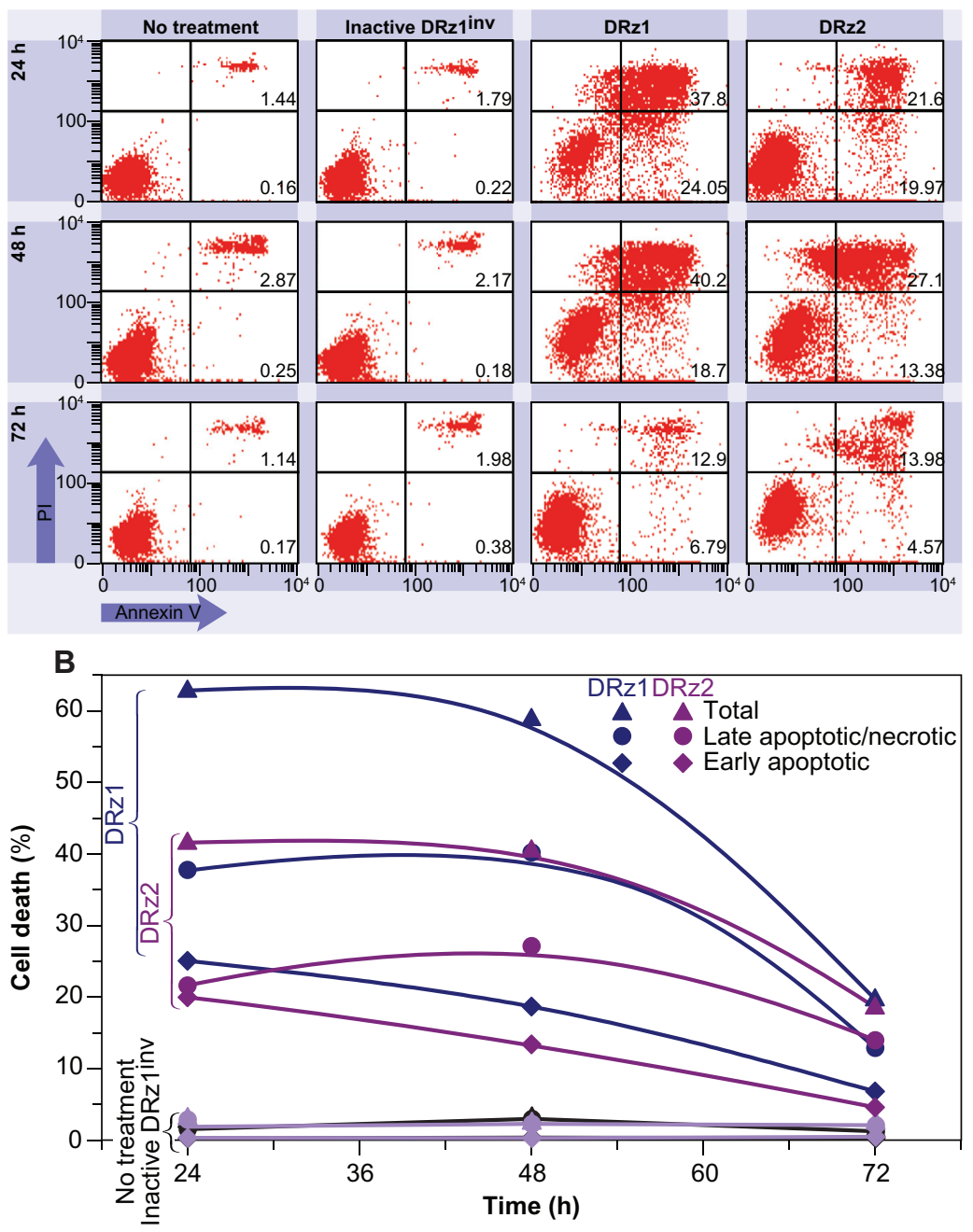

Figure 7 Representative flow cytometric assessment of apoptosis via annexin $\mathrm{V}$ and $\mathrm{PI}$ staining.

Notes: (A) SMMC-772I cells were treated with $4 \mu \mathrm{g} / \mathrm{mL}(0.39 \mathrm{pmol} / \mu \mathrm{L}) \mathrm{DRz}$ I and DRz2, and kept in culture for 72 hours. Every 24 hours, $\sim 10^{5}$ cells were analyzed with flow cytometry following annexin V-FITC/PI staining to evaluate changes in the apoptotic population. (B) Graphical representation of the flow cytometry cell death data in (A). Notice that DRzl induces nearly twice as much cell death as DRz2 and that the late apoptotic and necrotic cell death induction remains stable for 48 hours, whereas the number of cells in the early apoptotic stages decreases.

Abbreviations: DRz, deoxyribozyme (DNAzyme); FITC, fluorescein isothiocyanate; PI, propidium iodide.

detection of small molecules (eg, adenosine, cocaine, or adenosine monophosphate) and proteins (eg, lysozyme or thrombin). ${ }^{34}$

IGF-II is an insulin-homologous multipeptide with insulin-type growth activity whose normal biological activity is to promote mitosis in various cell types, especially during fetal development. Recent experimental evidence, however, has shown that elevated expression of IGF-II occurs in preneoplastic lesions, and high levels have also been found in more advanced stages of malignant $\mathrm{HCC}$ transformation. ${ }^{35}$ The human IGF-II gene is under the control of four different promoters (P1-P4), of which $\mathrm{P} 3$ is predominantly reactivated in liver cancer - $\mathrm{P} 3$ is normally quiescent in the adult liver - and, consequently, is one of the factors that promote uncontrolled hepatocyte proliferation. Furthermore, P3 is believed to be the most active promoter, controlling most of the translation of the IGF-II gene into mRNA in HCC.

Because of IGF-IIP3's purported involvement in the development and progression of various forms of liver cancer and the unique catalytic properties of DNAzymes, we designed two 10-23 DNAzymes that target IGF-IIP3 mRNA as a potential genic therapeutic option to counteract IGFIIP3's tumor-promoting action. In this stage of our investigations, no special precautions were taken to prevent possible endogenous degradation in the HCC cells during the experiments, since we aimed to evaluate the efficacy of the DRzs per se and in the absence of possible unwanted effects by stabilizing strategies such as phosphorothioate 


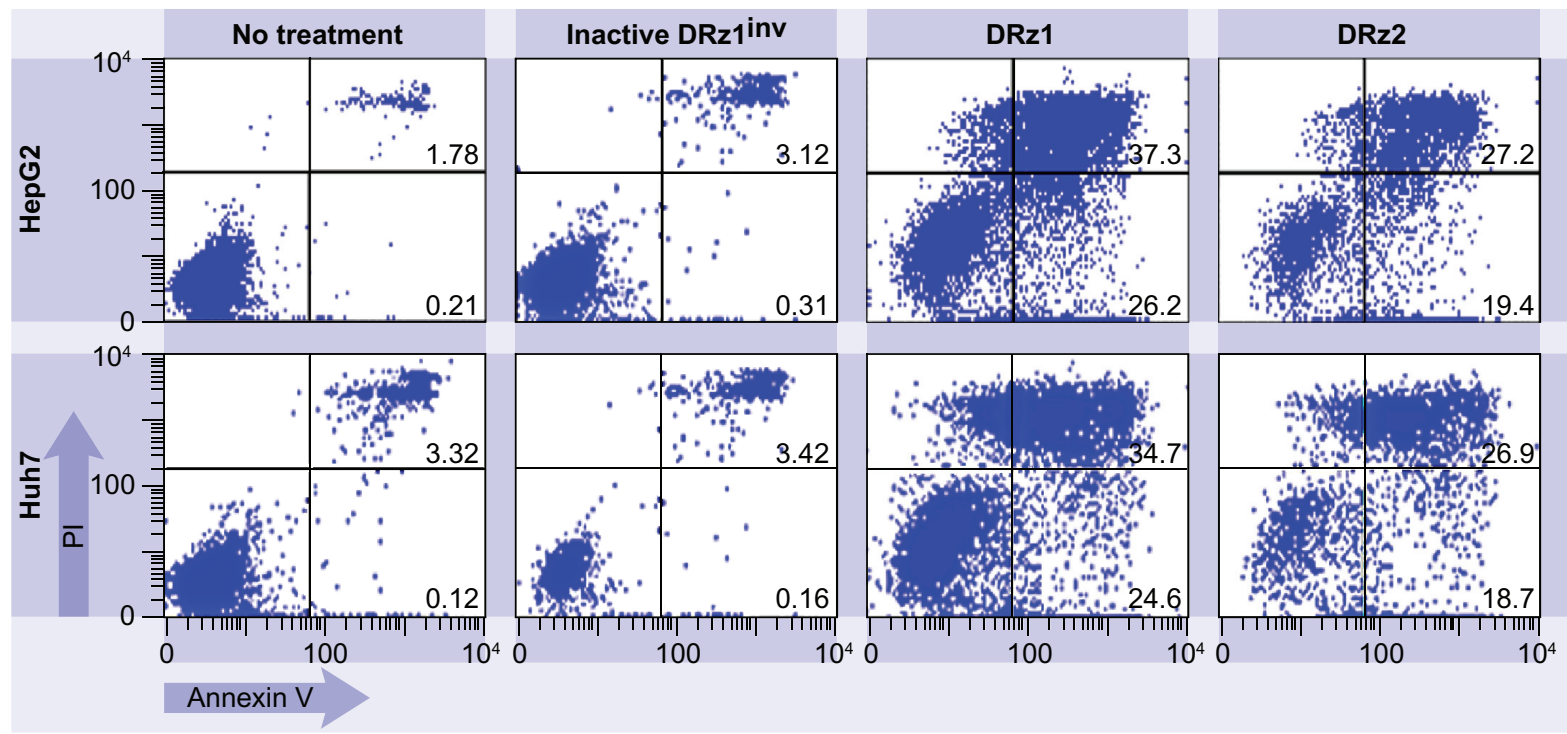

Figure 8 Representative flow cytometric assessment of apoptosis via annexin $\mathrm{V}$ and PI staining.

Note: HepG2 and Huh7 cells were treated with $4 \mu \mathrm{g} / \mathrm{mL}(0.39 \mathrm{pmol} / \mu \mathrm{L}) \mathrm{DRzl}$ and DRz2 and kept in culture for 24 hours $\left(\sim 10^{5}\right.$ cells were analyzed with flow cytometry). Abbreviations: DRz, deoxyribozyme (DNAzyme); PI, propidium iodide.

protection. Phosphorothioate linkages not only render the oligonucleotide more resistant to degradation, but it has been suggested that such alterations in antisense oligodeoxynucleotides may cause sequence-independent effects, such as an increased affinity for cellular proteins,${ }^{36}$ induce toxicity, ${ }^{37}$ or provoke immunologic responses in vivo. ${ }^{38}$

In the present work, the phenotypes of cultured HCC cells, ie, SMMC-7721, HepG2, and Huh7, were analyzed after DRz-mediated IGF-IIP3 knockdown. Our results show that both DRzs were able to inhibit the expression of IGF-IIP3, effectively repress cell proliferation, and induce apoptosis. In direct comparison, DRz1 was shown to be more effective than DRz2 in downregulating the expression of IGF-IIP3, which is likely a direct result of the careful design of DRzl's action against the initiator of IGF-IIP3 mRNA (AUG) translation. Both the reduction in mRNA and protein expression was in the same order of magnitude, at approximately $50 \%-60 \%$. Cell proliferation was transiently attenuated by nearly $30 \%$ in SMMC-7721 cells after the first 24 hours and dropped to $\sim 15 \%$ over the next 48 hours. Microscopic assessment showed that DRz treatment induced apoptosis, as deduced from distinct morphological changes in the nuclei. Further evaluation over a large population of cells via flow cytometry confirmed that both DRzs could induce early apoptosis in $\sim 25 \%$ of the SMMC-7721 cell population. These results were in concordance with the fluorescence micrographic assessment $(\sim 30 \%$ apoptotic nuclei in SMMC-7721 cells incubated with DRz1). Strikingly, DRz1 more efficiently induced late-stage apoptosis and necrosis $(\sim 40 \%)$, and this effect remained stable for up to 48 hours. DRz1 was shown to notably downregulate the expression of procaspase- 3 and procaspase-9, and concomitantly increase caspase- 3 and caspase-9. These results suggest that DRz1 might induce apoptosis caspase-dependently through the intrinsic and mitochondrial pathway. Similar apoptosis-promoting effects were recently reported for Dz13, a DNAzyme targeted at c-jun that induces apoptosis in a caspase-2 dependent way, ${ }^{39}$ and via upregulation of E2F1 transcription factor that causes upregulation of a number of proapoptotic genes. ${ }^{24}$ Therefore, evaluation of further off-target effects and affected proteins is highly significant and might provide a better insight as to how DRz1 influences other mechanisms.

Overall, even though no special precautions were taken to prevent DRz degradation, the efficacies in reducing IGFII protein expression and induce apoptosis are in the same order of magnitude as constructs used in similar research. For instance, Wu et a $1^{40}$ used DRz constructs that were substituted with phosphorothioate to specifically inhibit $\mathrm{p} 210^{\text {bcrabl }}$ oncogene expression in K562 chronic myeloid leukemia cells and achieved a $\sim 40 \%$ reduction in $\mathrm{p} 210^{\text {bcr-abl }}$ expression and $50 \%$ inhibition of cell growth over a 6-day period. Conversely, Liang et $\mathrm{a}^{41}$ achieved a nearly $80 \%$ decrease in survivin protein levels in the PANC-1 human pancreatic carcinoma cell line, 72 hours after a single transfection. This 10-23 anti-survivin DRz was protected from exonuclease degradation on the $5^{\prime}$ and $3^{\prime}$ termini by a phosphorothioate linkage and a spacer-C 3 cap. The transient nature of the reduction in IGF-IIP3 expression, cell proliferation, and apoptotic cell death, and the fact that the 

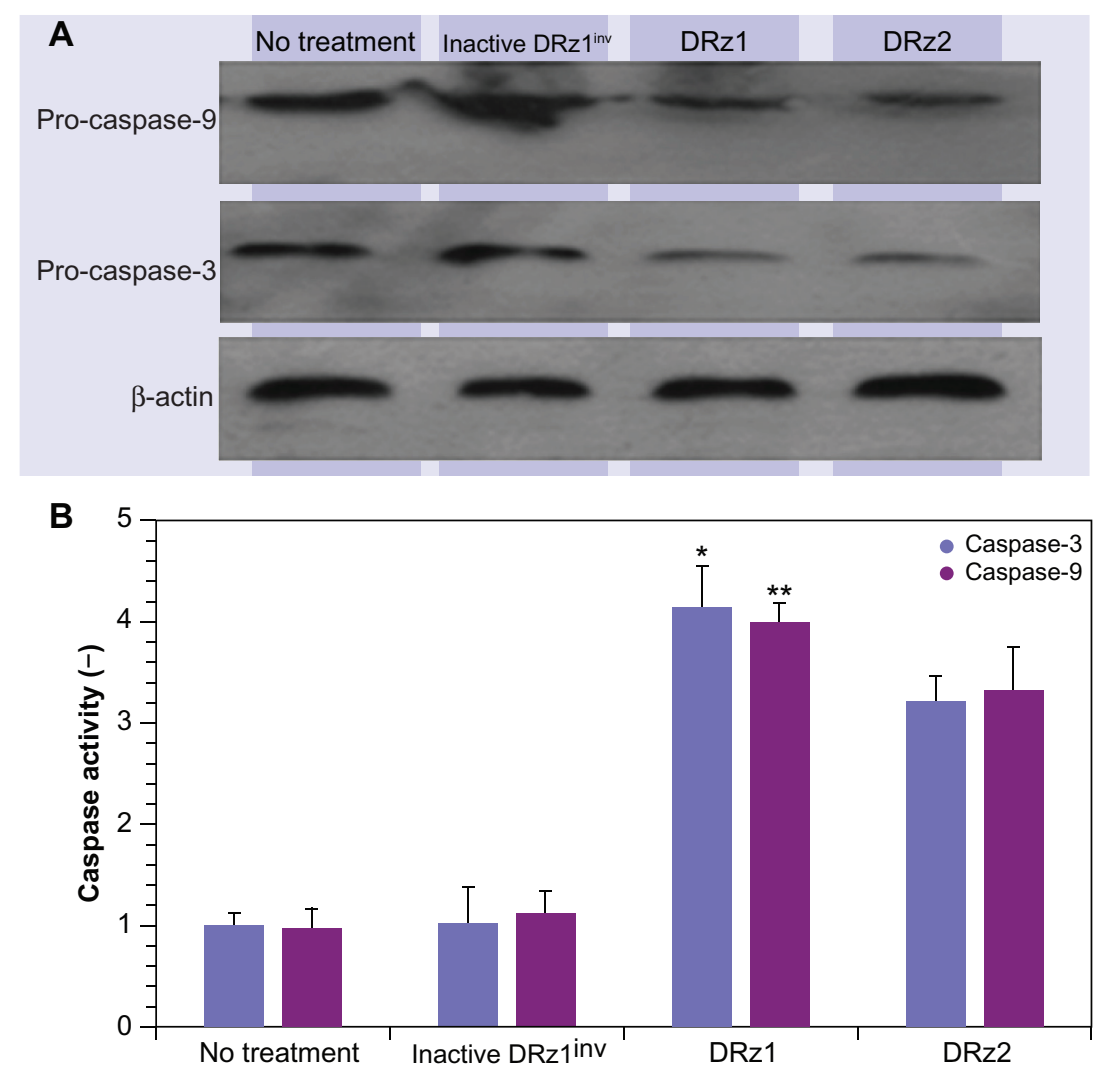

Figure 9 Evaluation of pro-caspase expression. (A) Western blot analysis. SMMC-772I cells were transfected with $4 \mu \mathrm{g} / \mathrm{mL}(0.39 \mathrm{pmol} / \mu \mathrm{L})$ DRzI or DRz2. Procapsase-3 and -9 levels were assessed after 24 hours' incubation via western blotting. A representative blot of three independent experiments is shown ( $\mathrm{n}=3$ ). Densitometry analysis showed that the protein signal densities in DRzl-treated cells were lower than in control cells (no treatment). (B) Effect of IGF-IIP3 DRzs on caspase-3 or -9 activity in SMMC-772I cells. The cells were kept in culture, treated with IGF-IIP3 DRzs for 24 hours, and subsequently analyzed for caspase-3 or -9 activity ( $\geq 3$ ). $* P<0.05$; $* * P<0.01$; *** $P<0.001$

Abbreviations: DRz, deoxyribozyme (DNAzyme); IGF-IIP3, insulin-like growth factor II promoter 3.

aforementioned effects cannot be reduced or induced beyond approximately $50 \%$, indicate that the DRzs are degraded by endogenous enzymes. That such degradation occurred was previously confirmed in vitro. Protection strategies of DRz1 based on locked nucleic acids might not only increase catalytic activity and lead to both a higher inhibition of IGF-IIP3 expression and longer stable inhibitory effect, but also afford protection towards 3'-exonucleolytic degradation, which is currently under investigation. Furthermore, research by both Tang et $\mathrm{al}^{42}$ and Uchida et $\mathrm{al}^{14}$ suggests a more prominent role for promoter $\mathrm{P} 4$ in $\mathrm{HCC}$ than previously assumed. Furthermore, P4 hypomethylation might be an early, and as the authors express it, frequent event in hepatocarcinogenesis, underscoring its possible importance. ${ }^{42}$ Therefore, reduction of IGF-II levels beyond 50\% might possibly only be achieved by combining DRz1 with a DRz targeted at IGF-IIP4 mRNA. Alternatively, or additionally, a concomitant knockdown of other factors reported to play important roles in HCC tumorigenicity, such as TGF- $\alpha$ (expressed in $80 \%$ of $\mathrm{HCC}^{43}$ ) and FZD-7 (upregulated in $90 \%{ }^{44}$ ), or the microRNAs miR-483-3 $\mathrm{p}^{45}$ and miR-221 ${ }^{46}$ (microRNA control might be particularly important in tumor reduction in intact animals) might produce more effective and extensive tumor cell death.

\section{Conclusion}

In general, our results demonstrate that targeting IGF-IIP3 with constructed DNAzymes might be a promising and potential therapeutic option in combating HCC, although further development is required. Even though DRz1 is capable of downregulating its target protein, the off-target effects are significant and should be the subject of further investigation. Future research will focus on achieving a higher efficacy in IGF-II reduction, including protection strategies of DRz1, development of IGF-IIP4-specific DNAzymes, and the use of improved transport vehicles for the DRzs. Additionally, since our collective investigations to date imply that IGF-IIP3 may play an important role in the neovascularization that promotes tumor growth in $\mathrm{HCC},{ }^{23}$ we are currently examining in more detail the impact of IGF-IIP3 DRz-based interventions on the development of neovascularization and transport in HCC. 


\section{Acknowledgments}

This work was partially supported by the governmental technology department of Jilin province under grant \#200505249, the governmental education department of Jilin province under grant \#2013188 (MZ and SL) and a Grant for External Collaborative Research AGE-2009 (GD).

\section{Author contributions}

MZ performed all experiments and helped to draft the manuscript. GPCD critically appraised the study, analyzed the data, made the figures, and wrote and revised the manuscript. SL was responsible for the conception, design, and supervision of the study as well as revising the manuscript. All authors read and approved the final manuscript.

\section{Disclosure}

GPCD is supported and partially exempted by Bio \& Nano-Solutions, Düsseldorf, Germany to pursue external collaborative fundamental scientific research. The authors report no other conflicts of interest in this work.

\section{References}

1. El-Serag HB. Hepatocellular carcinoma. $N$ Engl J Med. 2011; 365(12):1118-1127.

2. Ferlay J, Shin HR, Bray F, Forman D, Mathers C, Parkin DM. GLOBOCAN 2008, Cancer Incidence and Mortality Worldwide: IARC CancerBase No 10. Lyon, France: International Agency for Research on Cancer. Available from: http://globocan.iarc.fr. Accessed May 12, 2013.

3. Cabibbo G, Latteri F, Antonucci M, Craxi A. Multimodal approaches to the treatment of hepatocellular carcinoma. Nat Clin Pract Gastroenterol Hepatol. 2009;6(3):159-169.

4. Marrero JA, Kudo M, Bronowicki JP. The challenge of prognosis and staging for hepatocellular carcinoma. Oncologist. 2010;15 Suppl 4: 23-33.

5. Chen PJ, Furuse J, Han KH, et al. Issues and controversies of hepatocellular carcinoma-targeted therapy clinical trials in Asia: experts' opinion. Liver Int. 2010;30(10):1427-1438.

6. Wilhelm SM, Adnane L, Newell P, Villanueva A, Llovet JM, Lynch M. Preclinical overview of sorafenib, a multikinase inhibitor that targets both Raf and VEGF and PDGF receptor tyrosine kinase signaling. Mol Cancer Ther. 2008;7(10):3129-3140.

7. Pollak M. Insulin and insulin-like growth factor signalling in neoplasia. Nat Rev Cancer. 2008;8(12):915-928.

8. Breuhahn K, Longerich T, Schirmacher P. Dysregulation of growth factor signaling in human hepatocellular carcinoma. Oncogene. 2006;25(27):3787-3800.

9. Breuhahn K, Schirmacher P. Reactivation of the insulin-like growth factor-II signaling pathway in human hepatocellular carcinoma. World J Gastroenterol. 2008;14(11):1690-1698.

10. Brissenden JE, Ullrich A, Francke U. Human chromosomal mapping of genes for insulin-like growth factors I and II and epidermal growth factor. Nature. 1984;310(5980):781-784.

11. Chao W, D'Amore PA. IGF2: epigenetic regulation and role in development and disease. Cytokine Growth Factor Rev. 2008;19(2): 111-120.

12. Qian B, Katsaros D, Lu L, et al. IGF-II promoter specific methylation and expression in epithelial ovarian cancer and their associations with disease characteristics. Oncol Rep. 2011;25(1):203-213.
13. Vernucci M, Cerrato F, Besnard N, et al. The H19 endodermal enhancer is required for Igf2 activation and tumor formation in experimental liver carcinogenesis. Oncogene. 2000;19(54):6376-6385.

14. Uchida K, Kondo M, Takeda S, Osada H, Takahashi T, Nakao A. Altered transcriptional regulation of the insulin-like growth factor 2 gene in human hepatocellular carcinoma. Mol Carcinog. 1997;18(4): 193-198.

15. McManus SA, Li Y. The structural diversity of deoxyribozymes. Molecules. 2010;15(9):6269-6284.

16. Schlosser K, Li Y. Biologically inspired synthetic enzymes made from DNA. Chem Biol. 2009;16(3):311-322.

17. He J, Zhang D, Wang Q, Wei X, Cheng M, Liu K. A novel strategy of chemical modification for rate enhancement of 10-23 DNAzyme: a combination of A9 position and 8-aza-7-deaza-2'-deoxyadenosine analogs. Org Biomol Chem. 2011;9(16):5728-5736.

18. Wang F, Elbaz J, Orbach R, Magen N, Willner I. Amplified analysis of DNA by the autonomous assembly of polymers consisting of DNAzyme wires. J Am Chem Soc. 2011;133(43):17149-17151.

19. Teng B, Xin D, Wen L, Cui S, Jin C. Research of 10-23 DNAZyme inhibit the expression of eIF4E genes. Lin Chung Er Bi Yan Hou Tou Jing Wai Ke Za Zhi. 2007;21(12):552-554. Chinese.

20. Verma N, Tripathi SK, Chaudhury I, Das HR, Das RH. iNOS-targeted 10-23 DNAzyme reduces LPS-induced systemic inflammation and mortality in mice. Shock. 2010;33(5):493-499.

21. Wang TH, Li WT, Yu SH, Au LC. The use of 10-23 DNAzyme to selectively destroy the allele of mRNA with a unique purine-pyrimidine dinucleotide. Oligonucleotides. 2008;18(3):295-299.

22. Kong DM, Xu J, Shen HX. Positive effects of ATP on G-quadruplexhemin DNAzyme-mediated reactions. Anal Chem. 2010;82(14): 6148-6153.

23. Zhang M, Zhao H, Luo F, Luo S, Shi W. IGF-II inhibitory DNAzymes inhibit the invasion and migration of hepatocarcinoma cells. Biotechnol Lett. 2011;33(5):911-917.

24. Dass CR, Tan ML, Galloway SJ, Choong PF. Dz13 induces a cytotoxic stress response with upregulation of E2F1 in tumor cells metastasizing to or from bone. Oligonucleotides. 2010;20(2):79-91.

25. Yu SH, Wang TH, Au LC. Specific repression of mutant K-RAS by 10-23 DNAzyme: sensitizing cancer cell to anti-cancer therapies. Biochem Biophys Res Commun. 2009;378(2):230-234.

26. Mosmann T. Rapid colorimetric assay for cellular growth and survival: application to proliferation and cytotoxicity assays. J Immunol Methods. 1983;65(1-2):55-63.

27. Zhou H, Tang Y, Liang X, et al. RNAi targeting urokinase-type plasminogen activator receptor inhibits metastasis and progression of oral squamous cell carcinoma in vivo. Int J Cancer. 2009;125(2):453-462.

28. Crawford ED, Wells JA. Caspase substrates and cellular remodeling. Annu Rev Biochem. 2011;80:1055-1087.

29. Riedl SJ, Salvesen GS. The apoptosome: signalling platform of cell death. Nat Rev Mol Cell Biol. 2007;8(5):405-413.

30. Taylor RC, Cullen SP, Martin SJ. Apoptosis: controlled demolition at the cellular level. Nat Rev Mol Cell Biol. 2008;9(3):231-241.

31. Liu GN, Teng YX, Yan W. Transfected synthetic DNA enzyme gene specifically inhibits Egr-1 gene expression and reduces neointimal hyperplasia following balloon injury in rats. Int J Cardiol. 2008;129(1):118-124.

32. Zhou J, Yang XQ, Xie YY, et al. Inhibition of respiratory syncytial virus of subgroups A and B using deoxyribozyme DZ1133 in mice. Virus Res. 2007;130(1-2):241-248.

33. Hallett MA, Teng B, Hasegawa H, Schwab LP, Seagroves TN, Pourmotabbed T. Anti-matrix metalloproteinase-9 DNAzyme decreases tumor growth in the MMTV-PyMT mouse model of breast cancer. Breast Cancer Res. 2013;15(1):R12.

34. Kosman J, Juskowiak B. Peroxidase-mimicking DNAzymes for biosensing applications: a review. Anal Chim Acta. 2011;707(1-2): 7-17.

35. Qiu LW, Yao DF, Zong L, et al. Abnormal expression of insulin-like growth factor-II and its dynamic quantitative analysis at different stages of hepatocellular carcinoma development. Hepatobiliary Pancreat Dis Int. 2008;7(4):406-411. 
36. Rockwell P, O’Connor WJ, King K, Goldstein NI, Zhang LM, Stein CA. Cell-surface perturbations of the epidermal growth factor and vascular endothelial growth factor receptors by phosphorothioate oligodeoxynucleotides. Proc Natl Acad Sci U S A. 1997;94(12): 6523-6528.

37. Wahlestedt C, Salmi P, Good L, et al. Potent and nontoxic antisense oligonucleotides containing locked nucleic acids. Proc Natl Acad Sci US A. 2000;97(10):5633-5638.

38. Fluiter $\mathrm{K}$, ten Asbroek AL, de Wissel MB, et al. In vivo tumor growth inhibition and biodistribution studies of locked nucleic acid (LNA) antisense oligonucleotides. Nucleic Acids Res. 2003;31(3):953-962.

39. Dass CR, Galloway SJ, Choong PF. Dz13, a c-jun DNAzyme, is a potent inducer of caspase-2 activation. Oligonucleotides. 2010;20(3): 137-146.

40. Wu Y, Yu L, McMahon R, Rossi JJ, Forman SJ, Snyder DS. Inhibition of bcr-abl oncogene expression by novel deoxyribozymes (DNAzymes). Hum Gene Ther. 1999;10(17):2847-2857.

41. Liang Z, Wei S, Guan J, et al. DNAzyme-mediated cleavage of survivin mRNA and inhibition of the growth of PANC-1 cells. J Gastroenterol Hepatol. 2005;20(10):1595-1602.
42. Tang SH, Yang DH, Huang W, Zhou HK, Lu XH, Ye G. Hypomethylated $\mathrm{P} 4$ promoter induces expression of the insulin-like growth factor-II gene in hepatocellular carcinoma in a Chinese population. Clin Cancer Res. 2006;12(14 Pt 1):4171-4177.

43. Kiss A, Wang NJ, Xie JP, Thorgeirsson SS. Analysis of transforming growth factor (TGF)-alpha/epidermal growth factor receptor, hepatocyte growth Factor/c-met,TGF-beta receptor type II, and p53 expression in human hepatocellular carcinomas. Clin Cancer Res. 1997;3(7): 1059-1066.

44. Merle P, de la Monte S, Kim M, et al. Functional consequences of frizzled-7 receptor overexpression in human hepatocellular carcinoma. Gastroenterology. 2004;127(4):1110-1122.

45. Veronese A, Lupini L, Consiglio J, et al. Oncogenic role of miR-483-3p at the IGF2/483 locus. Cancer Res. 2010;70(8):3140-3149.

46. Callegari E, Elamin BK, Giannone F, et al. Liver tumorigenicity promoted by microRNA-221 in a mouse transgenic model. Hepatology. 2012;56(3):1025-1033.
Drug Design, Development and Therapy

\section{Publish your work in this journal}

Drug Design, Development and Therapy is an international, peerreviewed open-access journal that spans the spectrum of drug design and development through to clinical applications. Clinical outcomes, patient safety, and programs for the development and effective, safe, and sustained use of medicines are a feature of the journal, which

\section{Dovepress}

has also been accepted for indexing on PubMed Central. The manuscript management system is completely online and includes a very quick and fair peer-review system, which is all easy to use. Visit http://www.dovepress.com/testimonials.php to read real quotes from published authors. 